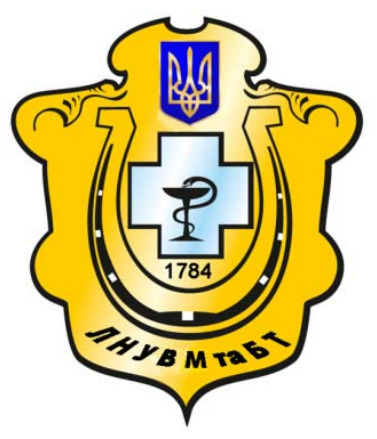

Науковий вісник Львівського національного університету ветеринарної медицини та біотехнологій імені С.3. Гжицького

Scientific Messenger of Lviv National University of Veterinary Medicine and Biotechnologies named after S.Z. Gzhytskyj

doi:10.15421/nvlvet6918

ISSN 2413-5550 print

ISSN 2518-1327 online

http://nvlvet.com.ua/

УДК 631.11:330.12

\title{
Особливості, чинники та функції товарної політики фермерських господарств
}

\author{
Н.Ю. Максимець \\ zamknena@gmail.com)
}

\begin{abstract}
Львівський наџіональний університет ветеринарної медицини та біотехнологій імені С.3. Гжицького, вул. Пекарська, 50, м. Львів, 79010, Україна
\end{abstract}

\begin{abstract}
У статті встановлено сутність процесу формування товарної політики фермерських господарств. Визначено особливості здійснення маркетингу у підприємствах такого типу. Досліджено чинники що впливають на проведення маркетингової товарної політики у фермерських господарствах. Ідентифіковано чинники, вплив яких відрізняє здійснення маркетингової товарної політики у фермерських господарствах та здійснення маркетингу, як такого на підприємствах сільського господарства від підприємств інших галузей. Вказано особливості проведення аграрного маркетингу за чинного становища у сільському господарстві України. Розглянуто основні об'єктивні та суб'єктивні сторони, щцо спричиняють складності у здійсненні ефективної маркетингової товарної політики фермерських господарствах. Проведене порівняння ринкових особливостей для фермерських господарств у краӥнах з розвинутою економікою та Україною.

Коротко відзначено перепони, що потрібно пройти фермерським господарствам на шляху до ринку сільськогосподарської продукиї Європейських краӥн. Встановлено ключові чинники, щяо мають вплив при формуванні товарної політики та вироблено механізм для постійного аналізу та врахування їх змін у процесі прийняття рішення.

Представлено особливу важливість маркетингового планування для фермерського господарства, враховуючи специфіку та важливість для населення сільськогосподарської продукиії.

Ключові слова: маркетингова товарна політика, маркетинг фермерських господарств, фермерські господарства, особливості формування товарної політики, особливості маркетингу в сільськогосподарських підприємствах.
\end{abstract}

\section{Особенности, факторы и функции товарной политики фермерских хозяйств}

\author{
Н.Ю. Максимец \\ zamknena@gmail.com)
}

\begin{abstract}
Львовский национальный университет ветеринарной медицины и биотехнологий имени С.3. Гжицкого, ул. Пекарская, 50, г. Львов, 79010, Украина
\end{abstract}

В статье установлено сущность процесса формирования товарной политики фермерских хозяйств. Определены особенности осущчествления маркетинга в предприятиях такого типа. Исследованы факторы, влияюшие на проведение маркетинговой товарной политики в фермерских хозяйствах. Идентифицировано факторы, влияние которых отличает осуществления маркетинговой товарной политики в фермерских хозяйствах и осуществления маркетинга как такового на предприятиях сельского хозяйства от предприятий других отраслей. Указано особенности проведения аграрного маркетинга за действуюшего положения в сельском хозяйстве Украины.

Рассмотрены основные объективные и субъективные стороны, вызывающие сложности в осуществлении эффективной маркетинговой товарной политики фермерских хозяйств. Проведено сравнение рыночных особенностей для фермерских хозяйств в странах с развитой экономикой и Украиной. Коротко отмечено преграды, которые нужно пройти фермерским хозяйствам на пути к рынку сельскохозяйственной продукция европейских стран.

Установлено ключевые факторы, влияющие при формировании товарной политики и выработан механизм для посто-

\section{Citation:}

Maksymets, N.Y. (2016). The aspects, factors and functions of farms' product policy. Scientific Messenger LNUVMBT named after S.Z. Gzhytskyj, $18,2(69), 92-95$ 
янного анализа и учета их изменений в процессе принятия решения.

Представлены особую важность маркетингового планирования для фермерского хозяйства, учитьвая специфику и важность для населения сельскохозяйственной продукиии.

Ключевые слова: маркетинговая товарная политика, маркетинг фермерских хозяйств, фермерские хозяйства, особенности формирования товарной политики, особенности маркетинга в сельскохозяйственных предприятиях

\title{
The aspects, factors and functions of farms' product policy
}

\author{
N.Y. Maksymets \\ zamknena@gmail.com) \\ Lviv National University of Veterinary Medicine and Biotechnologies named after S.Z. Gzhytskyj, \\ Pekarska Str., 50, Lviv, 79010, Ukraine
}

In this article, the meaning of the farms' product policy forming process is defined. The marketing aspects on such type of companies are specified. The factors that affect the marketing product policy on farms were analysed.

The factors, influence of which distinguish the marketing of product policy on farms, and marketing, as such, at the agricultural companies from companies of other branches, are identified. The aspects of agricultural marketing in the current situation in agriculture in Ukraine were pointed. The main objective and the subjective side, causing difficulty in implementing effective marketing product policy of farms. A comparison of market characteristics for farms in countries with developed economies and Ukraine.

Briefly noted obstacles which are needed to pass by farms on the way to market of agricultural products of European countries. Established the key factors that have influence in the formation of product policy and produced a mechanism to continuously review and consideration of changes in the decision-making process.

Presented particular importance of marketing planning for farming, given the specificity and importance for the population of agricultural products.

Key words: the marketing product policy, the marketing of farms, farms, the aspects of product policy forming, marketing aspect at agricultural companies.

\section{Вступ}

Фермерські господарства є перспективною формою господарювання у сільському господарстві. Але розглядати ії відірваною від реалій в яких доводиться проводити діяльність не можна. Так на функціонування таких господарств має вплив низка зовнішніх та внутрішніх чинників. По за тим фермерство $\epsilon$ невід'ємною складовою у валовому виробництві сільськогосподарської продукції Європейських країн, так і України.

Така форма господарювання має свої переваги перевірені та визнані часом, у більшості економічно розвинутих країн.

Така форма господарювання, як фермерське господарство в Європі добре відома своєю ефективністю ведення та гнучкістю до змінних умов. В Україні фермери зіштовхуються із низкою перепон, як низькі закупівельні ціни, не сформованість ринкового середовища, високі кредитні відсоткові ставки, низький рівень впровадження інновацій у виробництво, нечітка політика держави щодо фермерських господарств, низький рівень впровадження сучасної техніки.

Зважаючи на особливості сільського господарства, здійснення маркетингової товарної політики у фермерських господарствах має відмінності, на їі розробку впливає низка специфічних чинників. Варто відмітити, що маркетингова товарна політика у аграрному бізнесі супроводжу весь процес виробництва від закупівлі сировини до продажу готового продукту кінцевому споживачу (Buhuts'kyy, 1998; Hor'ovyy, 2007).

Має зміст встановити особливості їі провадження в нинішніх умовах, що склались в Україні. Маркетингова товарна політика $є$ важливим складником, без нормального функціонування і розуміння, якого не- можливо забезпечити ефективної роботи підприємства.

Аналіз останніх досліджень та публікащій. Вивченням проблеми фермерських господарств в Україні та проблематикою маркетингової товарної політики займались вітчизняні та зарубіжні вчені, такі, як I. Белебех, С. Греков, В. Горьовий, В. Горлачук, В. Галащук, І. Гоголь, С. Крикавський, Н. Криковцева, Н. Кортєльова, Я. Ларіна, А. Павленко, Г. Пересадько, Н. Ткаченко та інші (Lobas, 1991; Lypchuk, 1997; Lypchuk et al., 2006).

Метою дослідження $є$ вивчення особливостей розробки та здійснення товарної політики фермерських господарств. Відповідно до мети вирішувались такі завдання як визначити основні чинники, що впливають на провадження маркетингової товарної політики у фермерських господарствах, особливості ведення аграрного маркетингу в Україні.

\section{Результати та їх обговорення}

В дослідженні змісту маркетингової товарної політики необхідно спочатку визначитись із особливою категорією, що має безпосередній вплив на товарну політику, а саме маркетинг в аграрних підприємствах.

Ця категорія в якійсь мірі об'єднує виробників продовольства та кінцевих споживачів, і охоплює весь ланцюжок від виробництва розподілу та просування продукції.

В Україні аграрний маркетинг, що здійснюється у фермерських господарствах має ряд особливостей.

Маркетингу та товарна політика, як його складова, зазвичай, здійснюється не підготовленими фахівцями, а безпосередньо фермером. Така специфіка має, як суб'єктивну так і об'єктивну сторону. Основною при- 
чиною суб'єктивної сторони є низька поінформованість підприємця про переваги та користь залучення фахівця у сфері маркетингу, що частково спричинено відносною новизною маркетингу у аграрному бізнесі. Друга причина випливає із першої, важливість здійснення маркетингового планування, важливість просування, рекламування. У разі наявності у штаті фермерського господарства фахівця 3 маркетингу спостерігається недостатнє інвестування для ефективного функціонування всього комплексу маркетингу і можливості проведення відповідних заходів.

Вже обумовлювалось раніше, що крім суб'єктивної сторони, здійснення маркетингової політики в аграрному секторі України зіштовхується із рядом об'єктивних проблем.

У товарній маркетинговій політиці необхідно враховувати той факт, що основний прибуток від провадження фермерської діяльності у рослинництві отримується осінню. А всі підготовчі роботи, закупівля техніки проводяться весною, яка зазвичай характеризується малим оборотом коштів. Звідси і випливає дефіцит обігових коштів та необхідність короткострокових банківських кредитів під авансовані сплати за продукцію, яка буде реалізована.

Значною відмінністю у веденні діяльності в аграрному секторі в країнах з розвиненою економікою від України є наявність великої кількості дрібних товаровиробників, які окремо не можуть значно впливати на загальне ринкове становище. Таким чином на ринку сільськогосподарської продукції країн з розвиненою економіку утримується баланс та саморегулювання. Велика кількість невеликих фермерських господарств забезпечують високий рівень ринкової конкуренції, що обумовлено легкістю входу й виходу 3 ринку, рішення про яке приймає сам фермер.

Здійснення товарної політики у фермерському господарстві зіштовхується із особливостями товару. Це переважно товари першої необхідності із невеликим терміном зберігання. Необхідна швидка доставка, оперативна реалізація, уникнення довгого складування, можливе швидке псування. Іншим аспектом є проблеми формування асортименту продукції, потрібно відштовхуватись від потреб споживача.

Вагомою проблемою розробки товарної політики $\epsilon$ нечітка державна політика у сфері підтримки та регулювання діяльності фермерських господарств, несприятлива податкова політика.

Перехідний період на шляху до ринку Європи в тому числі має стресову складову для фермерського господарства. В першу чергу це пов'язано із новими вимогами до якості продукції, іiі стандартизації, безпечності. Варто зазначити, що ринок із сталими вищими вимогами до якості продукції за роки привчив своїх покупців, тому рухатись вітчизняним фермерам потрібно вже у напрямку сформованої кон'юнктури.

Незважаючи на доходи та ціну обсяг купівлі більшості продукції сільськогосподарського виробництва залишається на одному рівні. Це зумовлено нееластичністю попиту на неї. В сьогоднішніх реаліях України значна частка доходу громадян спрямована на купівлю продуктів харчування i кожна додаткова гривня йде на купівлю додаткової одиниці продукції харчування (закупівля основних видів овочів та фруктів на холодний період року). По за тим потрібно пам'ятати про закон граничної корисності, відповідно до якого при зростанні доходів громадян попит на товари першої необхідності майже не зростатиме. Інший не менш важливий закон Енгеля, який свідчить, що зі збільшенням доходу споживачі будуть купувати дорожчі та цінніші продовольчі товари.

Ще одним важливим чинником є земля, яка виступає водночас як ресурс та засіб виробництва. Характеристики грунту, а саме верхнього його шару значною мірою зумовлюють характер фермерської діяльності, та його маркетингової товарної політики. Надважливим є збереження родючого шару. Надто інтенсивне виробництво однорідної продукції може виснажити його, тому плануючи товарну політику у фермерському господарстві обов'язково потрібно це враховувати.

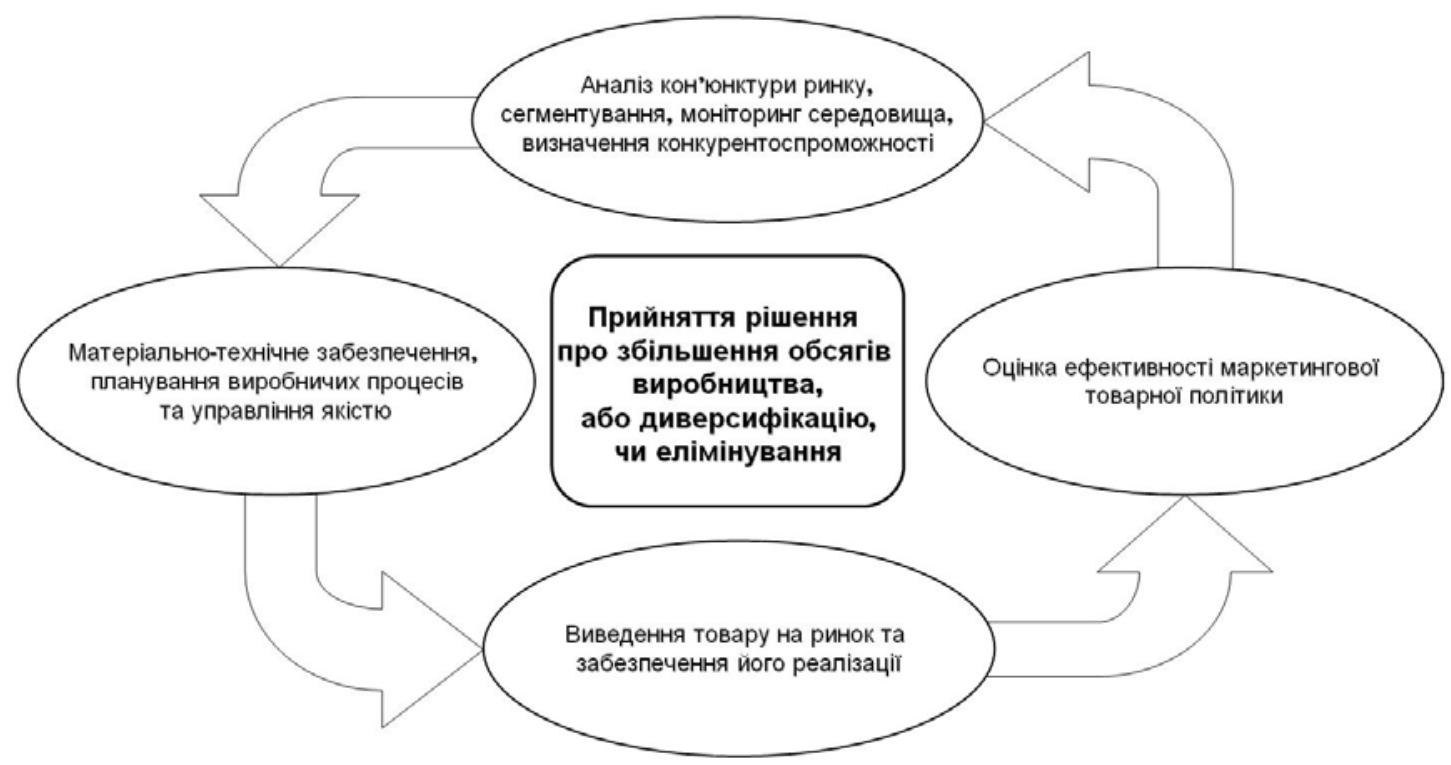

Рис. 1 Основні чинники ефективної товарної політики фермерських господарств 
Розробка товарної політики здійснюється в умовах диспаритету цін на промислові товари та продукцію сільського господарства. Нерівномірна зміна рівня ціни на технічні засоби, парк яких потрібно регулярно оновлювати і ціни на сільськогосподарську продукцію з якої має дохід фермерське господарство.

В цілому стратегічні підходи до розробки маркетингової товарної політики фермерських господарств варто розділити на:

- сегментування, визначення місця товару на ринку, аналізу специфіки обраного сегменту, місця товару в сегменті

- проведення аналізу доцільності подолання ринкових бар'єрів

- проведення аналізу кон'юнктури ринку

- постійний моніторинг маркетингового середовища фермерського господарства

- постійне підвищення конкурентоспроможності продукції

Слід виокремити основні передумови розробки ефективної товарної політики у фермерських господарствах. Наочніше буде зобразити їх схематично (рис. 1).

На ефективне функціонування та якісне впровадження маркетингової товарної політики впливають такі чинники, забезпечивши які можна досягнути оптимального результату. Система, що поставлена мінімізовувати їх вплив має циклічний характер. Це безперервний процес, що забезпечує якісне прийняття рішення у товарній політиці.

На ефективне функціонування та якісне впровадження маркетингової товарної політики впливають такі чинники, забезпечивши які можна досягнути оптимального результату. Система, що поставлена мінімізовувати їх вплив має циклічний характер. Це безперервний процес, що забезпечує якісне прийняття рішення у товарній політиці.

\section{Висновки}

Завдання маркетингової товарної політики не можна розглядати, як сукупність цілей окремого комплексу заходів, а як основний елемент маркетингової діяльності фермерського господарства. Всі заходи маркетингу в тому числі товарної політики повинні бути спрямовані на забезпечення максимального прибутку. Для цього слід враховувати цілу низку особливостей сільськогосподарської діяльності.

Розробка товарної політики в господарстві займається не спеціально підготовлений фахівець, а сам фермер. В нього відсутнє остаточне розуміння, які переваги отримає підприємство із застосуванням маркетингової товарної політики. 3 цього випливає проблема малого інвестування для здійснення маркетингу. Має місце погана поінформованість керівників господарств про важливість маркетингового планування та реалізації усіх засад маркетингу.

\section{Бібліографічні посилання}

Buhuts'kyy, Yu.O. (1998). Rozvytok fermers'kykh hospodarstv v Ukrayini. Ekonomika APK. 6, 25-28 (in Ukrainian).

Hor'ovyy, V.P. (2007). Fermerstvo Ukrayiny: teoriya, metodolohiya, praktyka : monohrafiya. K. : NNTs IAE. (in Ukrainian).

Lypchuk, V.V. (1997). Selyans'ki (fermers'ki) hospodarstva: otsinka i problemy stanovlennya ta rozvytku. L'viv : Vil'na Ukrayina (in Ukrainian).

Lypchuk, V.V., Hnatyshyn, L.B., Kordob, O.M. (2006). Fermers'ki hospodarstva: stan, problemy ta stratehiyi rozvytku : monohrafiya. L'viv: Mahnoliya (in Ukrainian).

Lobas, H.G. (1991). Organizacija fermerskih hozjajstv, kooperativov, arendnyh podrazdelenij, akcionernyh obshhestv i firm v sel'skom hozjajstve v uslovijah perehoda k rynochnoj jekonomike. K. : Urozhaj (in Russian).

Стаття надійшла до редакиії 10.10.2016 